\title{
Manganese Nodules Residue: Potential Raw Material for FeSiMn Production
}

\author{
N. S. Randhawa ${ }^{1}$, R. K. Jana ${ }^{1, *}$, N. N. $\operatorname{Das}^{2}$ \\ ${ }^{1}$ MEF Division, CSIR-National Metallurgical Laboratory, Jamshedpur, 831007, India \\ ${ }^{2} \mathrm{P}$ G Department of Chemistry, North Orissa University, Baripada, 757 003, India
}

\begin{abstract}
The manganese nodule residue, generated in reduction roast ammonia leaching process has emerged as potential secondary raw material for production of ferrosilicomanagese. In the present paper, the smelting studies of low manganese containing leached manganese nodules residue blended with high grade Mn ore has been carried out in electric arc furnace for ferrosilicomanganese production. The optimum charge mix has been derived to produce the standard grade alloy as per Bureau of Indian Standards (BIS) specifications. The residue to ore blending ratio of 1:0.6 with 18\% quartz addition at basicity 0.2 has been found to yield the standard grade ferrosilicomanganese alloy with about $77 \%$ manganese recovery.
\end{abstract}

Keywords Manganese Nodule Residue, Smelting, Silicomanganese, Manganese Ore

\section{Introduction}

Land based high grade manganese ore deposits have been the main resource of manganese metal. The largest use of manganese is in the form of ferromanganese, silicomanganese and other ferroalloys. The other uses are making of batteries, chemicals, aluminum cans etc[1]. Another resource of manganese has been found in deep ocean at the depth of 2000-5000 meters called manganese nodules or sea nodules. They have unique feature of containing copper, nickel \& cobalt along with appreciable amount of manganese[2]. The manganese content in these nodules is generally below $30 \%$ and hence, it can be categorized as low grade manganese ore. Several processes have been developed for processing of manganese nodules with the aim of extracting copper, nickel and cobalt. NML, Jamshedpur has developed a process based on reduction roasting-ammonia leaching -solvent extraction-electrowining route to recover $\mathrm{Cu}, \mathrm{Ni} \& \mathrm{Co}$ as metals[3]. However, during the leaching process of roast-reduced manganese nodules, a huge quantity of residue is generated, which is almost $70 \%$ of the nodules treated. This residue contains significant amount of manganese (26\%), iron (10\%) and silica (16\%). The leached residue cannot be directly employed for silicomanganese smelting due to lower $\mathrm{Mn} / \mathrm{Fe}$ ratio (2-3) than generally required[4]. However, it can be blended with manganese ore to improve $\mathrm{Mn} / \mathrm{Fe}$ ratio.

The present work involves studies on use of leached manganese nodule residue for silicomanganese production.

* Corresponding author:

rkjana@nmlindia.org (R. K. Jana)

Published online at http://journal.sapub.org/ijmee

Copyright (C) 2012 Scientific \& Academic Publishing. All Rights Reserved
The leached residue has been blended with high grade $\mathrm{Mn}$ ore and smelted in $50 \mathrm{kVA}$ electric arc furnace. The effect of $\mathrm{Mn} / \mathrm{Fe}$ ratio, $\mathrm{Mn} / \mathrm{Si}$ ratio and charge basicity on metallic yield, manganese and silicon recovery have been studied by varying the addition of manganese ore, quartzite and dolomite.

\section{Experimental}

\subsection{Raw Materials}

The leached manganese nodule residue used for smelting studies was obtained from large scale leaching trail of manganese nodules at CSIR-National Metallurgical Laboratory, Jamshedpur, India. The residue was washed with water for removal of ammonia and entrapped leach liquor. Washing was performed by agitating the leach residue in a steel vessel with $\mathrm{L} / \mathrm{S}$ ratio of 10 for $1 \mathrm{hr}$. Chemical composition of washed residue and other raw materials, as determined by conventional chemical methods and atomic $\mathrm{Ab}$ sorption spectrometer (PerkinElmer, AAnalyst 400), are given in Table 1. The washed and dried residue was pelletized on a disc pelletizer $(100 \mathrm{~cm}$ diameter) by sprinkling water. The size of residue pellets ranged between 5-10 mm.

The ground manganese ore was also pelletized to $5-10 \mathrm{~mm}$ size pellets before addition to charge mix. All other raw materials viz. coke, dolomite, quartzite etc. were crushed to 5-8 $\mathrm{mm}$ size for charge mix preparation.

\subsection{Electric Arc Furnace and Smelting Operation}

The charge mix was smelted in a small electric arc furnace for silicomanganese production. The experimental set up consisted of a graphite electrode, a graphite crucible, thick 
carbon base plate and a refractory jacket. Schematic diagram of experimental furnace is shown in Figure 1. The graphite electrode was fitted into a water cooled brass clamp and was connected to the phase point of the $50 \mathrm{kVA}$ AC power source. The electrode holding clamp was connected to vertically movable arm. The graphite crucible was placed on the carbon block, which was connected to the neutral point of the power source. The crucible was covered by a lid fitted with insulation bricks, to avoid heat losses during smelting.

Every smelting experiment started with initial heating of crucible by arcing for 10 minutes with small amount of coke. In all the smelting trials, the arc was started with power input of $40 \mathrm{~V}$ and 700 Amps. Heating up of crucible was followed by addition of small amounts of charge mix in the crucible. As smelting proceeded, further charge mix addition was made to the crucible.

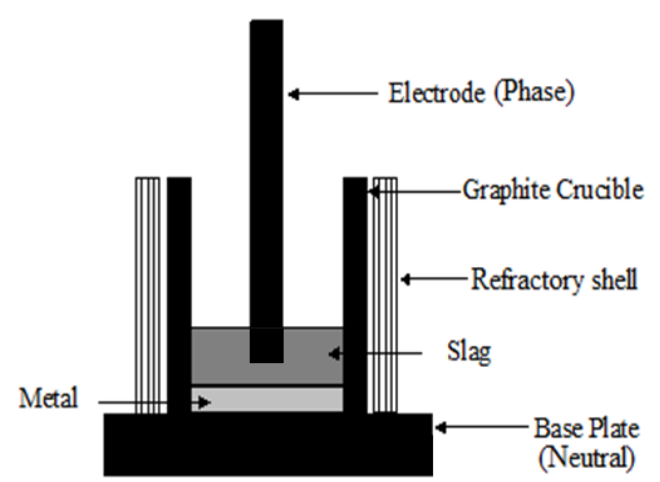

Figure 1. Schematic diagram of experimental setup for residue smelting

The power input of 400-600 Amps was maintained throughout the smelting. Soaking time of 15 minutes was provided after the complete melting of charge mix to facilitate completion of reduction reactions and proper slag metal separation. During smelting, temperature was monitored by infrared pyrometer.

\section{Results and Discussion}

The chemical analysis given in Table 1 shows that leach manganese nodule residue is low manganese material with manganese to iron ratio of 2.56 . This also depicts that manganese nodule residue is somewhat similar to ferruginous-siliceous type manganese ore in chemical composition and cannot be directly subjected to silicomanganese production[5]. Since the $\mathrm{Mn} / \mathrm{Fe}$ is of prime importance for production of a particular grade of alloy, low manganese containing materials like leached manganese nodule residue should be blended with high grade manganese containing material so that $\mathrm{Mn} / \mathrm{Fe}$ ratio is more than that required in final alloy (after considering losses during smelting). The target silicomanganese grade was Si16Mn63 having composition $\mathrm{Mn}=60-65 \%, \mathrm{Si}=14-17 \%, \mathrm{C}=2.5 \% \%_{\max }, \mathrm{S}=0.03_{\max }$ and $\mathrm{P}=0.3 \%_{\max }[6]$. Typically charge mix consisted of $1 \mathrm{Kg}$ blend of leach residue and Mn ore in different ratios, which was further mixed with quartz, dolomite and coke. The residue: Mn ore blend were prepared in ratios of 1:0.4, 1:0.6, $1: 0.8$ and $1: 1$ giving rise to different $\mathrm{Mn} / \mathrm{Fe}$ ratios. The $\mathrm{Mn} / \mathrm{Si}$ ratios in the charge mix were maintained by quartzite addition from $13 \%$ to $26 \%$ (by mass) of residue-ore blend. The composition of charge mixes with different $\mathrm{Mn} / \mathrm{Fe}$ and $\mathrm{Mn} / \mathrm{Si}$ ratio are given in Table 2. The slag characteristics have been maintained in terms of basicity $\left(\mathrm{B}=\mathrm{CaO}+\mathrm{MgO} / \mathrm{SiO}_{2}\right)$ and $\mathrm{R}$ ratio $\left(\mathrm{CaO}+\mathrm{MgO} / \mathrm{Al}_{2} \mathrm{O}_{3}\right)$, which have been reported to be determining factor for the manganese and silicon distribution across metal-slag interface[7]. The silicomanganese smelting is usually carried out with acidic slag $(\mathrm{B}<1)$. Eissa et al showed that $\mathrm{R}$ ratio of 1.8 was optimum for silicomanganese production[8]. In present studies, $\mathrm{R}$ ratio of 1.8 was maintained in all the charge mixes by addition of alumina whereas two basicity ratios, 0.2 and 0.3 , were maintained by addition of dolomite.

Table 1. Chemical composition of raw materials

\begin{tabular}{|c|c|c|c|c|c|c|}
\hline$\%$, by mass & Leached residue & Mn Ore & Quartzite & Dolomite & Coke & Alumina \\
\hline $\mathrm{Fe}$ & 10.19 & 8.29 & 1.45 & 0.22 & $0.31 *$ & \\
\hline $\mathrm{Fe}_{2} \mathrm{O}_{3}$ & 14.58 & 11.84 & 2.07 & 0.31 & & \\
\hline $\mathrm{Mn}$ & 26.11 & 48.25 & & & & \\
\hline $\mathrm{MnO}$ & 17.7 & & & & & \\
\hline $\mathrm{Mn}_{2} \mathrm{O}_{3}$ & 7.06 & & & & & \\
\hline $\mathrm{MnO}_{2}$ & 11.42 & & & & & \\
\hline $\mathrm{CaO}$ & 0.36 & 3.87 & 0.092 & 17.58 & $* 0.81$ & \\
\hline $\mathrm{MgO}$ & 4.4 & 0.37 & 0.042 & 31.01 & $* 0.63$ & \\
\hline $\mathrm{SiO}_{2}$ & 16.44 & 4.18 & 97.3 & 4.16 & $* 8.36$ & \\
\hline $\mathrm{Al}_{2} \mathrm{O}_{3}$ & 3.04 & 1.22 & 0.5 & 0.41 & $* 4.56$ & 99.0 \\
\hline $\mathrm{P}$ & 0.19 & & & & $* 0.06$ & \\
\hline $\mathrm{S}$ & 0.081 & & & & $* 0.34$ & \\
\hline LOI & 17.01 & & & 42.41 & & \\
\hline Moisture & 1.5 & 0.85 & & & 0.87 & \\
\hline Ash & & & & & 17.44 & \\
\hline $\mathrm{FC}$ & & & & & 76.65 & \\
\hline $\mathrm{VM}$ & & & & & 3.96 & \\
\hline
\end{tabular}

*Analysed in coke ash; $\mathrm{LOI}=$ Loss on ignition; $\mathrm{FC}=$ Fixed carbon; $\mathrm{VM}=$ Volatile matter 
Table 2. Composition of charge material (values in grams)

\begin{tabular}{|c|c|c|c|c|c|c|c|c|c|c|}
\hline Heat no. & $w$ MNR & Mn Ore & Quartzite & Dolomite & Alumina & Coke & $*$ R:O & $* *$ Basicity & $\mathrm{Mn} / \mathrm{Fe}$ & $\mathrm{Mn} / \mathrm{Si}$ \\
\hline 1 & 710 & 290 & 151 & 19 & 5 & 243 & $1: 0.4$ & 0.2 & 3.3 & 2.5 \\
\hline 2 & 625 & 375 & 178 & 28 & 8 & 260 & $1: 0.6$ & 0.2 & 3.5 & 2.5 \\
\hline 3 & 555 & 445 & 199 & 32 & 10 & 278 & $1: 0.8$ & 0.2 & 3.7 & 2.5 \\
\hline 4 & 500 & 500 & 216 & 37 & 12 & 291 & $1: 10$ & 0.2 & 3.9 & 2.5 \\
\hline 5 & 710 & 290 & 150 & 81 & 21.5 & 244 & $1: 0.4$ & 0.3 & 3.3 & 2.5 \\
\hline 6 & 625 & 375 & 178 & 88 & 24 & 261 & $1: 0.6$ & 0.3 & 3.5 & 2.5 \\
\hline 7 & 555 & 445 & 199 & 98 & 28 & 277 & $1: 0.8$ & 0.3 & 3.7 & 2.5 \\
\hline 8 & 500 & 500 & 216 & 103 & 30 & 291 & $1: 10$ & 0.3 & 3.9 & 2.5 \\
\hline 9 & 625 & 375 & 255 & 58 & 16 & 283 & $1: 0.6$ & 0.2 & 3.5 & 2.0 \\
\hline 10 & 625 & 375 & 213 & 42 & 12 & 272 & $1: 0.6$ & 0.2 & 3.5 & 2.25 \\
\hline 11 & 625 & 375 & 153 & 19 & 6 & 256 & $1: 0.6$ & 0.2 & 3.5 & 2.75 \\
\hline 12 & 625 & 375 & 130 & 9 & 3 & 250 & $1: 0.6$ & 0.2 & 3.5 & 3.0 \\
\hline
\end{tabular}

* $\mathrm{R}: \mathrm{O}=$ leach residue:manganese ore

$* *$ Basicity is defined as $(\mathrm{CaO}+\mathrm{MgO}) / \mathrm{SiO}_{2}$

Temperature (K)

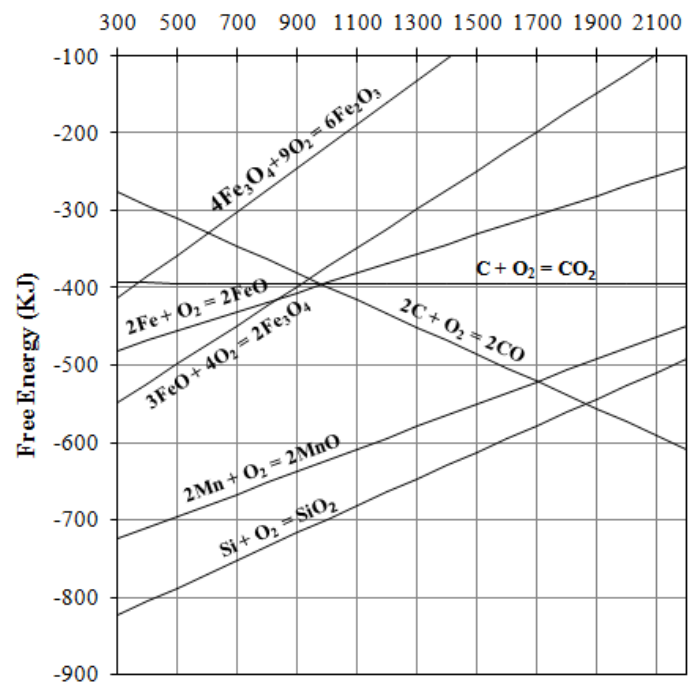

Figure 2. Free energy diagram for carbothermic reduction of $\mathrm{Si}, \mathrm{Mn}$ and Fe oxides

An idea about the temperature requirement of the carbothermic reduction of oxides present in the leach residue for silicomanganese production can be obtained from the Ellingham diagram (Figure 2). The required temperature may be $1600 \pm 50^{\circ} \mathrm{C}$. The probable reactions during the smelting process may be as given below[7]:

$$
\begin{gathered}
(\mathrm{MnO})+\underline{\mathrm{C}}=\mathrm{Mn}+\mathrm{CO}_{(\mathrm{g})} \\
2(\mathrm{MnO})+\underline{\mathrm{Si}}=2 \underline{\mathrm{Mn}}+\left(\mathrm{SiO}_{2}\right) \\
\left(\mathrm{SiO}_{2}\right)+\underline{\underline{\mathrm{C}}}=\underline{\mathrm{Si}}+2 \mathrm{CO}_{(\mathrm{g})} \\
\left(\mathrm{SiO}_{2}\right)+\underline{\mathrm{C}}=\mathrm{SiO}(\mathrm{g})+\mathrm{CO}_{(\mathrm{g})} \\
\mathrm{SiO}_{(\mathrm{g})}+\underline{\mathrm{C}}=\underline{\mathrm{Si}}+\mathrm{CO}_{(\mathrm{g})} \\
(\mathrm{FeO})+\mathrm{CO}_{(\mathrm{g})}=\underline{\mathrm{Fe}}+\mathrm{CO}_{2(\mathrm{~g})}
\end{gathered}
$$

\subsection{Effect of Leached Residue: Mn Ore Blending Ratio and Basicity}

The studies on required ratios of leached residue : manganese ore blending and charge basicity for standard grade silicomanganese production were done by smelting of charge mixes of heat no. 1-8 (Table 2). The chemical composition of alloys obtained from heat no $1-4$ for $\mathrm{B}=0.2$ and $5-8$ for $\mathrm{B}=$ 0.3 are given in Figure 3 and Figure 4 respectively, along with target $\mathrm{Mn}, \mathrm{Si}$ and $\mathrm{C}$ content.
The alloy obtained from heat nos. $2,3,4,6,7, \& 8$ conformed to the target specification whereas alloys from heat no. 1 and 5 were having lower Mn content compared to the standard grade. The increase in $\mathrm{Mn} / \mathrm{Fe}$ ratio resulted in improved grade of alloy with higher Mn content. This is due to the increased $\mathrm{MnO}$ availability in the slag for reduction with higher amount of Mn ore addition in the charge. The Mn \& Si recovery and metallic yield from heat no. $1-8$ are given in Figure 5, 6 and 7, respectively.

The metallic yield and $\mathrm{Mn} \& \mathrm{Si}$ recoveries were found to be higher when charge mix were smelted at basicity 0.2 than at 0.3 , in all the cases. This is perhaps due to more fluidity of molten bath at lower basicity.

The higher yield and metallic recovery at charge basicity 0.2 is in agreement in use of charge mix basicity mentioned in literature $[9,10]$. Although, the use of $\mathrm{Mn} / \mathrm{Fe}$ ratio $>4$ for the silicomanganese production from smelting of $\mathrm{Mn}$ ore-FeMn slag/Mn rich slag have been reported in the literature $[9,10]$, in the present studies, the minimum $\mathrm{Mn} / \mathrm{Fe}$ ratio required for the silicomanganese production using leached manganese nodule residue and Mn ore is 3.5 (residue to $\mathrm{Mn}$ ore $=1: 0.6$ ) on both the basicity.

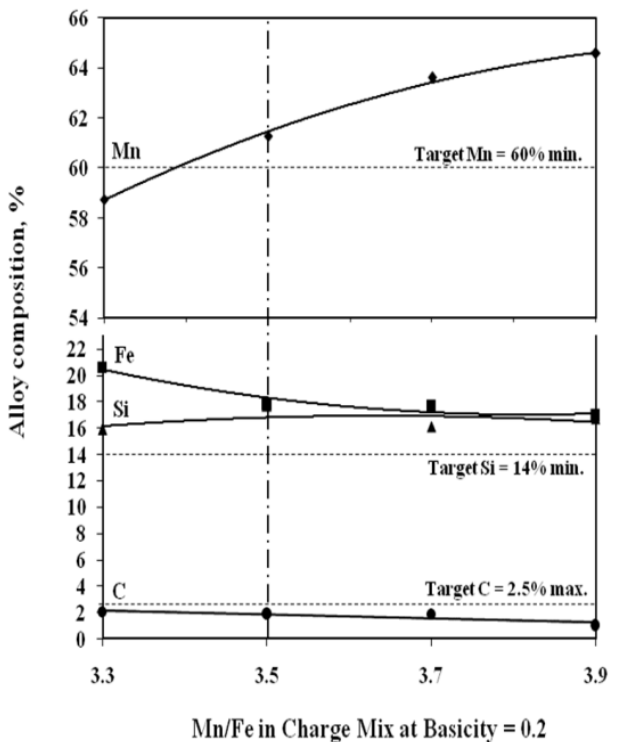

Figure 3. Chemical composition of obtained at different residue:ore ratio at basicity 0.2 


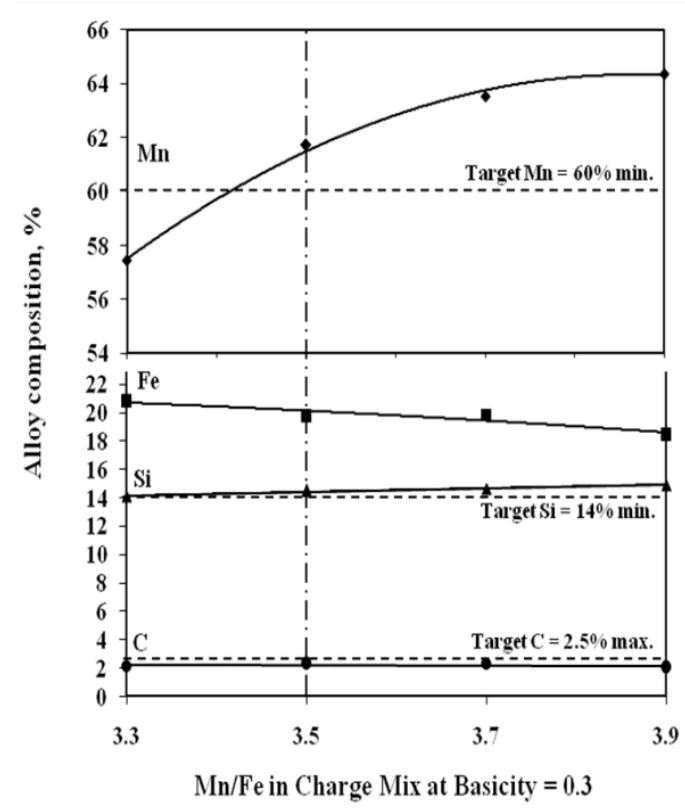

Figure 4. Chemical composition of obtained at different residue:ore ratio at basicity 0.2

\subsection{Optimizing Quartz Addition}

Silica in the charge mix has dual role, first as source of silicon and second as fluxing agent. In present work, silica addition in the charge mix is maintained by quartzite addition in the charge mix. The charge mixes of heat no. 9-12 were smelted to investigate the effect of quartz addition on smelting yield. In these charge mixes, quartz addition was varied from 13 to $26 \%$ of leach residue-manganese ore blend (1:0.6). The chemical compositions of alloys obtained at various quartzite additions are given in Fig. 8, which show that quartzite additions up to about $18 \%$ produce alloy conforming to the targeted silicomanganese composition with $77 \%$ manganese recovery. The quartz addition more than about $18 \%$ resulted in decreasing manganese content than that required for standard grade. However, required Si content in the alloy was obtained in the entire range of quartz addition. Therefore, quartz addition up to about $18 \%$ was found to be necessary for producing standard grade silicomanganese alloy.

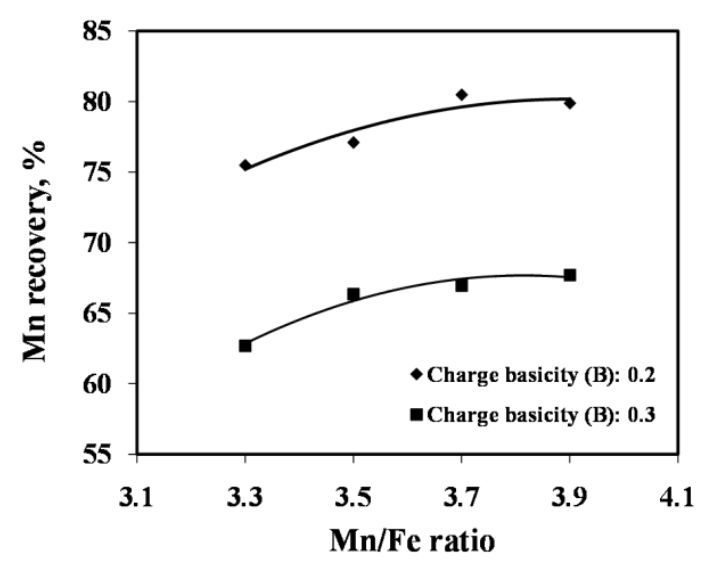

Figure 5. Effect of leached residue : Mn ore ratio on Mn recovery

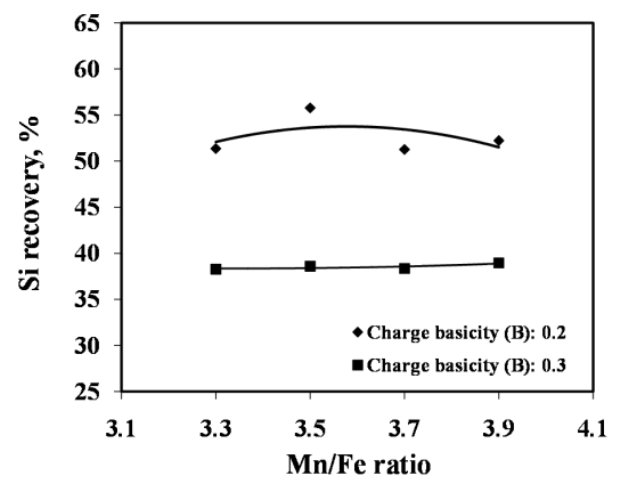

Figure 6. Effect of leached residue : Mn ore ratio on Mn recovery

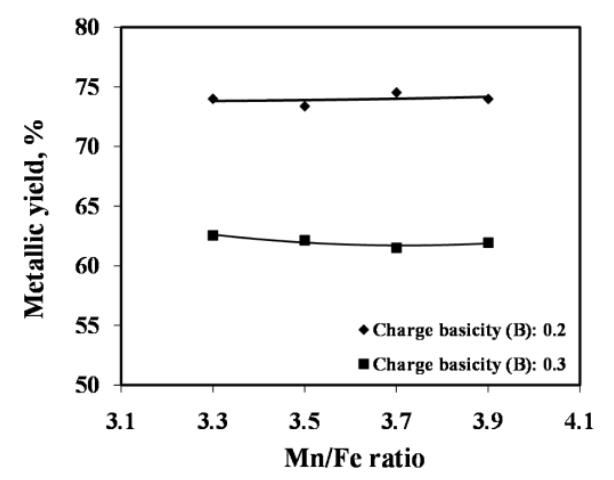

Figure 7. Effect of leached residue : Mn ore ratio on metallic yield

The effects of quartz addition on manganese recovery, silicon recovery and metallic yield are given in Figure 9, 10 and 11, respectively. The addition of quartz in the charge mix was found to be associated with decreased metallic yield. The decrease in metallic yield was due to decreasing $\mathrm{Mn}$ recovery with the addition of quartz. Although, there was increase in Si recovery but not enough to compensate the losses due to decreased Mn recovery.

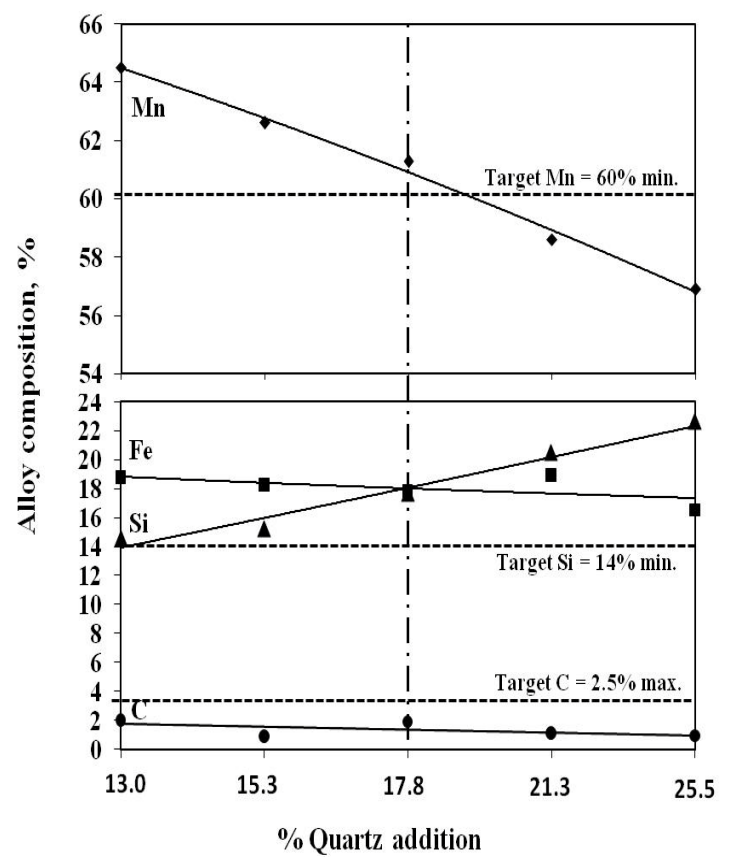

Figure 8. Chemical composition of obtained at different quartz addition (Heat no. 9-12 and 2) 


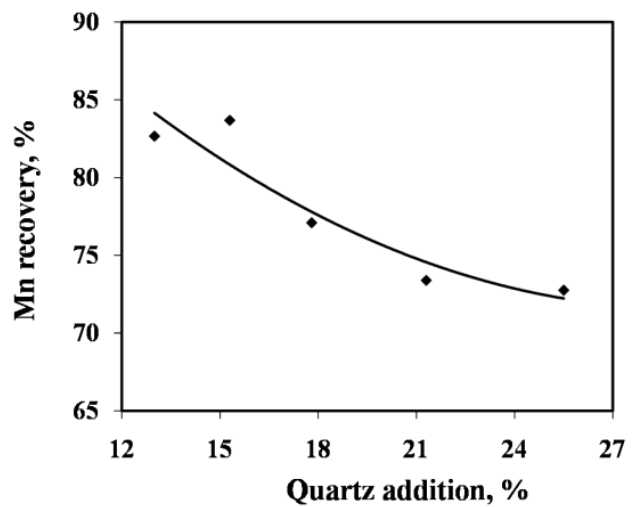

Figure 9. Effect of quartz addition on Mn recovery

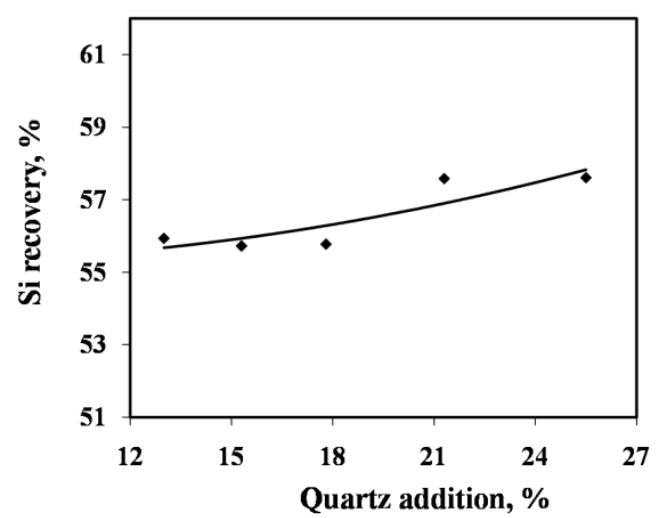

Figure 10. Effect of quartz addition on Mn recovery

In a melt, reduction of manganese and silicon mainly takes place from their combined oxides as shown below, which is rather difficult than reduction from their free oxides[8].

$$
\left(\mathrm{MnO} . \mathrm{SiO}_{2}\right)+3 \underline{\mathrm{C}}=\underline{\mathrm{MnSi}}+3 \mathrm{CO}_{(\mathrm{g})}
$$

$\left(\mathrm{MnO} \cdot \mathrm{SiO}_{2}\right)+(\mathrm{CaO} \cdot \mathrm{MgO})=(\mathrm{MnO})+(\mathrm{CaO} \cdot \mathrm{MgO}) \mathrm{SiO}_{2}$

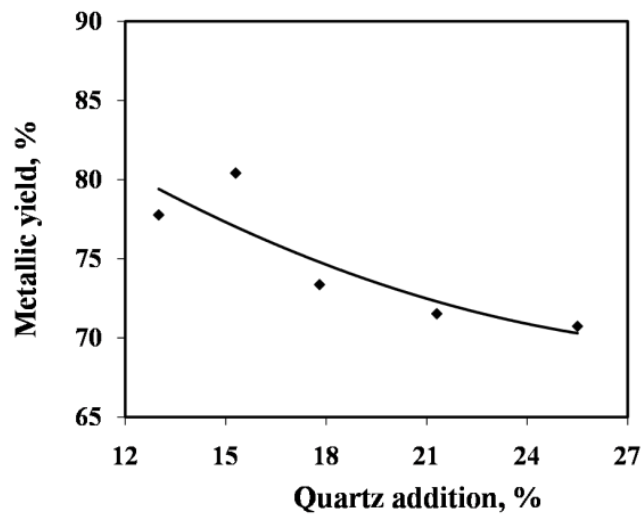

Figure 11. Effect of quartz addition on metallic yield

Presence of basic oxides such as $\mathrm{CaO}$ and $\mathrm{MgO}$ form stabler silicates and generate free $\mathrm{MnO}$ available for reduction by carbon. However, with the addition of silica in slag, $\mathrm{MnO} \mathrm{SiO}_{2}$ type complex is formed, which limits the activities of free $\mathrm{MnO}$ and hence affect $\mathrm{MnO}$ reduction to $\mathrm{Mn}$. Thus, an increase in silica addition resulted in increased silicon content and decrease in manganese recovery. Addition of silica also increases the slag liquidus, which intern lead to higher bath temperature favorable for Si recovery.

\section{Conclusions}

The low manganese containing leached manganese nodule residue can be utilized for silicomanganese production by blending with high grade manganese ore. The metallic yield and $\mathrm{Mn} \& \mathrm{Si}$ recoveries are found to be higher when charge mixes were smelted at basicity 0.2 than at 0.3 . It is found that charge mix should contain leached manganese nodules residue: $\mathrm{Mn}$ ore of 1:0.6 or more and quartz addition $\leq 18 \%$ for standard grade silicomanganese (Si16Mn63) production. The $77 \%$ manganese recovery from smelting of charge mix having leach residue : Mn ore $=1: 0.6,18 \%$ quartz and basicity 0.2 is achieved. Utilisation of leach residue for silicomanganese production will not only ensure its bulk utilisation but also minimize the environmental problem but economics of the manganese nodules processing will also be improved. Production of silicomanganese from leached residue would also improve the overall economics of manganese nodules processing

\section{ACKNOWLEDGEMENTS}

The authors wish to express their gratitude to the Director, CSIR-NML, Jamshedpur for the kind permission to publish this paper.

\section{REFERENCES}

[1] T. Vulcan. (2009) Manganese: An Unsung Hero. [Online]. Available:

http://www.hardassetsinvestor.com/component/content/articl e/1682.html

[2] Bombara, G. and Maisano S., 1985, Prospects for metals and materials from deep sea ores., Meter. Sci. Technol., 3(1), 22-28.

[3] Jana, R.K., Pandey, B.D. and Premchand, 1999, Ammoniacal leaching of roast reduced deep-sea manganese nodules, Hydrometallurgy, 53, 45-56.

[4] M. Riss and Y. Khodororovsky, Production of ferroalloys, Mir Publishers, Moscow, 1967

[5] A. Peravadhanulu, P. D. Prasada Rao, G. P. Mathur and V. A. Altekar:, Monograph on Ores and Mineral in India, Vol. II, Part III (The Statesman Commercial Press, Kolkata), 1979.

[6] IS1470, Indian Standard: SILICOMANGANESE SPECIFICATION (Third Revision),. Bureau of Indian Standards, New Delhi, 1990.

[7] S. E. Olsen, M. Tangstad, and T. Lingstad: Production of Manganese ferroalloys, Tapir Academic Press, Trondheim, Norway, 2007.

[8] M. Eissa, A. Fathy, A. Ahmed, A. El-Mohammady and K. El-Fawakhary, "Factors affecting silicomanganese production using manganese rich slag in the charge," in Proc. INFACON X, 2004, p 245 (The South African Institute of Mining and Metallurgy: South Africa). 
[9] B. Monsen, M. Tangstad and H. Midtgaard, "Use of charcoal in silicomanganese production, in Proceedings Tenth International Ferroalloys Congress", in Proc. INFACON X, 2004, p 392 (The South African Institute of Mining and Metallurgy:
South Africa).

[10] El-Faramway, H., Matter, T., Fathy, A., 2004, Eissa, M.and Ahmed, A. H., Silicomangnese production from Mn rich slag, Ironmaking and Steelmaking, 31(1), 31-36. 